\title{
The Three-Level Model (3LM): A Conceptual Framework for the Integration of Naqli and Aqli Knowledge In Medicine
}

\author{
Razrim $\mathrm{R}^{\mathrm{a}}$, Mohd Faisal $\mathrm{M}^{\mathrm{b}}$, Affirul Chairil $\mathrm{A}^{\mathrm{a}}$, Mohd Rushdan $\mathrm{MJ}^{\mathrm{c}}$ \\ ${ }^{a}$ Faculty of Medicine and Health Sciences, Universiti Sains Islam Malaysia, Kuala Lumpur, Malaysia \\ ${ }^{\mathrm{b}}$ Faculty of Syariah and Law, Universiti Sains Islam Malaysia, Negeri Sembilan, Malaysia \\ ${ }^{\mathrm{C}}$ Faculty of Leadership and Management, Universiti Sains Islam Malaysia, Negeri Sembilan, Malaysia
}

\section{INTRODUCTION}

For Muslims, the learning and practice of scientific knowledge, although superficially appears similar to the practices of secular scientists, have differences in the aspect of epistemology. Due to the influences of secularism and western modernism in the past few centuries, the modern science which we are accustomed to now is devoid of Tawhid (the unity and uniqueness of God as creator and sustainer of the universe) ${ }^{1}$ and relies heavily on Positivism (the belief that knowledge comes from things that can be experienced with the senses or proved by logic). ${ }^{2}$ On the other hand, Muslims believe that God is the ultimate source of all true knowledge, either obtained through revelation (naqli knowledge) or acquired by observation, experimentation, and deduction (aqli knowledge). The concept of integration of knowledge was embraced by our great Muslim scholars of the past such as Ibn Sina, al-Farabi, al-Kindi, and Ibn Firnas, just to name a few; but the eventual fall of the Islamic civilisation has resulted in the epistemology of natural sciences as propagated by the Western civilisation gaining prominence. The efforts to correct these misconceptions in Malaysia has been spearheaded by the International Islamic University of Malaysia (IIUM) by its Islamisation of Human Knowledge agenda ${ }^{3}$ and by Universiti Sains Islam Malaysia (USIM) with its vision for the integration of Naqli and Aqli knowledge. ${ }^{4}$

\section{Corresponding Author:}

\section{Dr. Razrim Rahim}

Faculty of Medicine and Health Sciences,

Universiti Sains Islam Malaysia,

Menara B, Persiaran MPAJ, Pandan Indah,

55100 Kuala Lumpur, Malaysia.

Tel No : +006-03-42892400

E-mail : razrimrahim@usim.edu.my
There have been several methods proposed in the efforts of Islamisation of Human Knowledge and Integration of Naqli and Aqli Knowledge (for this article the phrase Islamisation and Integration of Knowledge will be used). Among them include al-Attas's two steps for Islamisation of contemporary knowledge, 5 alFaruqi's twelve steps for Islamisation of modern knowledge, ${ }^{6}$ al-Awani's six discourses for Islamisation of knowledge, ${ }^{7}$ and Kamal Hassan's Tawhidic Science Framework. ${ }^{8}$ The aforementioned methods are approaches with the main concern of providing the ideal epistemological and philosophical concepts for Islamisation and Integration of knowledge. In our opinion, a conceptual framework that encompasses the philosophical aspects of knowledge, when combined with the more practical aspects of scientific practice, can further contribute to the agenda of Islamisation and Integration of knowledge. Thus we are proposing the Three-Level Model (3LM) as an attempt to achieve this purpose.

For a conceptual framework to be relevant and useful, we believe that several criteria should be met. The framework must be accurate, simple, comprehensive, and relevant. Accuracy has been the raison de etre of the efforts of Islamisation and Integration of knowledge. The accurate Islamic Worldview, especially concerning Tawhid, is of utmost importance. The framework should also be simple. Muslim scientists who are not well versed in the philosophical and conceptual aspects of Islamisation and the Integration of knowledge should find the framework easy to understand. Thus the framework is summarised in a schematic diagram for ease of understanding. To achieve comprehensiveness, important aspects in the practice of Muslim scientists 
should be included in the framework. This includes Aqidah (Islamic Theology), Syariah (Islamic Law), and Akhlaq (Morality); besides other practical aspects specific for the Muslim scientist to achieve excellence in his scientific endeavor such as creativity, collaboration, and keeping abreast of his or her field. Relevancy is important for the framework to gain acceptance among scientists. The scientists should know where they can contribute and how they fit in within the framework. For this reason, we have used medical practitioners (clinicians, medical scientists, medical lecturers) as an example for this conceptual framework. With two of the authors being practicing clinicians, we also provide input based on practical viewpoints. The relevancy of this framework should also apply to other fields of scientific knowledge.

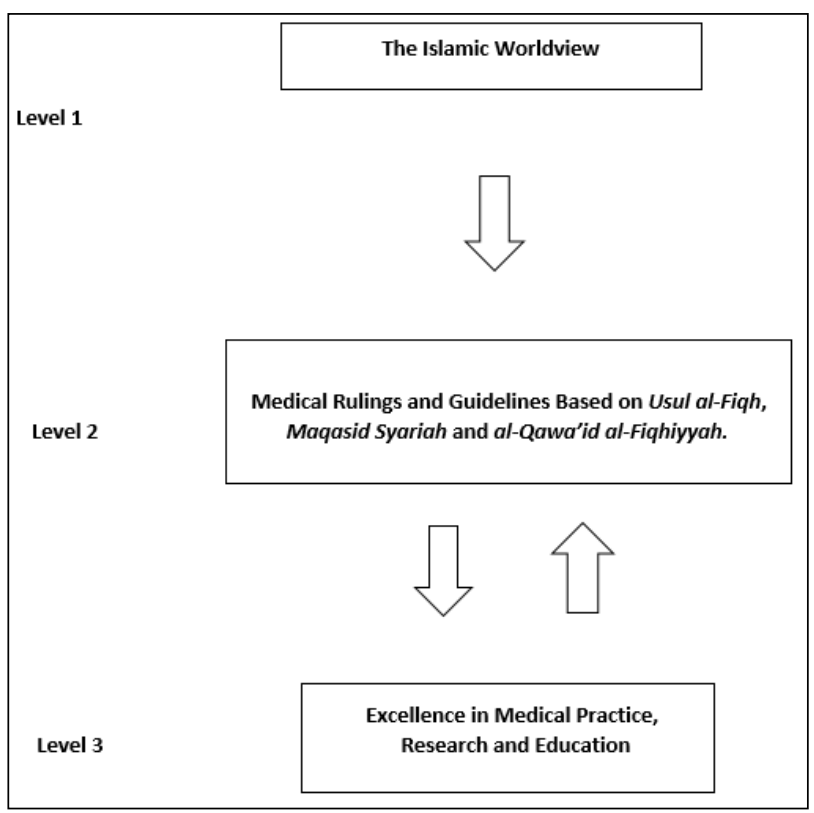

Figure 1: The Three-Level Model (3LM) for the Integration of Naqli and Aqli Knowledge in Medicine

The Three-Level Model (3LM) is a schematic representation of a conceptual framework for the integration of naqli and aqli knowledge. As the name denotes, the framework consists of three schematic boxes of which Level 1 is 'The Islamic Worldview', Level 2 is 'Medical Rules and Guidelines Which are Based on Usul al-Fiqh, Maqasid Syariah and al-Qawa'id alFiqhiyyah' and Level 3 is 'Excellence in Medical Practice, Research, and Education'. The higher the level, the more important and authoritative the knowledge is. There are arrows that represent the relationships between the boxes. The arrow from Level 1 to Level 2 only points downwards denoting that The Islamic Worldview influences the other two levels, but is not influenced by them. On the other hand, the arrow between Levels 2 and 3 points to both directions, denoting that Level 2 influences Level 3 and vice versa.

\section{Level 1: The Islamic Worldview}

A worldview is a comprehensive conception or apprehension of the world, especially from a specific standpoint. ${ }^{9}$ According to al-Attas:

' The worldview of Islam comprises both the al-dunya and al-akhirah aspects; in which the dunya aspect is related profoundly to the akhirah aspect, and in which the akhirah aspect has ultimate and final significance'. ${ }^{10}$

The Islamic Worldview in scientific knowledge has been formulated by Muslim scholars and scientists after gaining a comprehensive understanding of the Book Of God (Al-Quran) and the teachings of His Prophet (peace be upon him). These two revealed sources of knowledge are the source of true knowledge and do not require authentication by experimentation, observation, or even logical deduction. Nevertheless, Muslims are encouraged to experiment, observe and use their facultative abilities to understand this true source of knowledge so that Muslims can increase their Iman (faith) as in the case of Prophet Ibrahim and the four birds:

"And (mentioned) when Ibrahim said, 'My Lord, show me how you give life to the dead'. (Allah) said,' Have you not believed?'. He said, 'Yes, but (I ask) only so that my heart be satisfied'...".11

This aspect of the epistemology of science from the Islamic Worldview is where it differs significantly from the epistemology of modern science. Islam acknowledges revealed and acquired knowledge whereas modern science mandates physical and observational pieces of evidence through its positivism worldview. According to the Islamic Worldview, if the findings of a scientific study appear to be at odds with its worldview, either the findings of the study are erroneous, the research methodology is flawed or we have not yet acquired the ability and tools to come to an accurate conclusion. 
The Islamic Worldview at Level 1 will then influence the other two levels.

Level 2: Medical Rulings and Guidelines Derived from Usul al-Fiqh, Maqasid Syariah and al-Qawa'id al-Fiqhiyyah.

The second or intermediate level in the 3LM is concerned with topics that govern and guide medical practitioners. This can be in the form of legal or Syariah rulings, clinical guidelines, or ethical practices. Level 2 is where Islamic scholars and medical experts meet to discuss and formulate medical rulings and guidelines. In the ideal scenario, the Islamic scholar and medical expert can even be the same person, showcasing an example of the human product of Islamisation and Integration of Knowledge, as exemplified by the aforementioned Islamic scholars above.

For this level, we find the adoption of three of the traditional methods or sources of Islamic rulings to be applicable within this framework. Firstly, the use of Usul al-Figh for the Islamization process has been suggested by many scholars including Abu Sulayman. ${ }^{12}$ Secondly, we find the Islamic Ethical Framework, proposed by Saifuddeen, ${ }^{13}$ also to be practical for this level. The Islamic Ethical Framework suggests the use of Maqasid Syariah when faced with any scientific or technological dilemma. And thirdly, we also find the utilisation of alQawa'id al-Fiqhiyyah to be useful for Level 2 of our framework.

Usul al-Fiqh is the source of Islamic law, and the discipline dedicated to elucidating them, and their relationship to the substantive rulings of law.14 These sources include the Quran, the Sunnah (sayings, actions and tacit approvals of the Prophet), Ijma' (consensus of Muslim scholars), Qiyas (analogy or rule by precedent), and $\operatorname{Urf}$ (customs). ${ }^{15}$

Maqasid Syariah is the higher objective of Islamic Law, where the reasons behind Islamic rulings from the Quran and Sunnah are studied before forming other derivative rulings. These objectives have traditionally been the protection and promotion of faith, soul, wealth, mind, offspring, and honour. ${ }^{16}$ More recently, $\mathrm{Al}$ -Qaradhawi further extended these objectives to include among others, freedom, social welfare, and human fraternity. ${ }^{17}$

Al-Qawa'id al-Fiqhiyyah is all-inclusive rules based on legal pieces of evidence written accurately in comprehensive words, ${ }^{18}$ or also known as Islamic legal maxims. The five major Islamic legal maxims are: certainty is not over-ruled by doubt, hardship begets facility, harm must be eliminated, the custom is accepted as the basis of judgement, and acts are judged by their intentions.

As mentioned earlier, Level 2 can also be influenced by Level 3, meaning that Muslim scientists and medical practitioners are encouraged to give feedback to correct a dictate in Level 2. Consider cigarette smoking as an example. Previous fatwas (Islamic ruling) on smoking was that it was either mubah (permissible) or makrub (not encouraged). In our framework, the formulation of fatwa would be in Level 2. But subsequent scientific studies conducted later (Level 3) have shown the clear relationship between smoking and severe diseases such as lung cancer and chronic obstructive pulmonary disease. This has resulted in several Islamic authorities revising the fatwa on smoking to be haram (not permissible). ${ }^{19,20}$

The utilisation of these three methods is hoped to be sufficient for Muslim scientists to use when confronted with a medically related dilemma in the majority of situations, and to act as a guide to stay within the correct Islamic Worldview and jurisprudence.

\section{Level 3: Excellence in Medical Practice, Research, and Education}

Level 3 is where medical practitioners conduct most of their medically related day-to-day activities. Clinicians see and treat patients, medical researchers conduct upto-date and beneficial studies, and medical lecturers educate future doctors; all within the framework of the Islamic Worldview and guided by rules and guidelines synthesized at Level 2. Any outwardly purely scientific activity, when done with the correct intention and is done within the framework of what is allowed in Islam, should result in the practitioner gaining Ajr (Reward) from Allah Ta’ala. Ibn Al-Qayyim said: 
"Allah has made devotion of worship to Him

Alone and following the Sunnah the means of deeds being accepted". ${ }^{21}$

Following the Sunnah in this context, which is to perform seemingly worldly medical activities, is taking the cue from the Hadith of the Prophet (peace be upon him):

\section{"You have a better knowledge of the affair of your world". 22}

This Hadith is evidence that in most scientific endeavours, there is much freedom granted by Islam. Kasule's definition of Islamic Medicine concludes this view accurately: Islamic Medicine is medicine whose basic paradigms, concepts, values, and procedures conform to or do not contradict the Quran and Sunnah. ${ }^{23}$

We have added 'Excellence' as part of the requirement when conducting medical activities. Excellence in medical practice and scientific activities is one of the signs of a developed civilisation. Excellence is also required by Islam. The Prophet (peace be upon him) said:

\section{"Verily, Allah has prescribed excellence in everything". ${ }^{24}$}

Among the attributes of excellent Muslim medical practitioners are good manners, knowledgable, skillful, charismatic, hard-working, and also taqarrub (sense of being close) to Allah. We felt obliged to add taqarrub to Allah as a required attribute since the aim of the framework is to produce successful human models of Islamisation and Integration of knowledge, Muslim scientists who are successful in the duniawi and ukhrawi aspects of life.

\section{Examples of 3LM in Practice}

Scenario 1: Dr. Ahmad is a liver transplant surgeon who trained in Europe. He is now interested to return to Malaysia and start a liver transplant surgery unit. The local community had some reservations with regards to some of the processes involved in transplantation such as the concept of brain death and using organs harvested from the dead to be transplanted into live patients. The hospital management arranged for discussions to be held between Dr. Ahmad, the local community, and the Department of Islamic Development (JAKIM). The liver transplant service was eventually started after everyone was satisfied that not only transplantation is permissible in Islam, it is also encouraged based on several dictates from Maqasid Syariah (preservation of life, preservation of honour) and al-Qawa'id al-Fiqhiyyah (harm must be eliminated, hardship begets facility).

The entire practice was aligned to the Islamic Worldview (Level 1), guidance was taken from Maqasid Syariah and al-Qawa'id al-Fiqhiyyah (Level 2), and Dr. Ahmad successfully started a thriving and active liver transplant unit (Level 3).

Scenario 2: Dr. Aminah has just started her career as a medical lecturer. She completed her Ph.D. at an institution in Europe where Darwinism evolution was widely accepted. She is about to start to teach embryology at a university in Malaysia. As part of her induction to this university, she was introduced to the concept of the Islamic Worldview, especially with regards to science. She has decided to always have the Islamic worldview concept as a guide in all her teaching activities. She prepares her teaching material based on the knowledge of embryology from standard textbooks, combined with what the Quran and Sunnah have mentioned with regards to embryology, ensuring what she teaches is within the correct Islamic worldview.

Dr. Aminah has the correct worldview (Level 1), which she combines with scientific verses from the Quran/ Usul Fiqh (Level 2), which she then uses in her medical teaching activities (Level 3).

\section{CONCLUSION}

The Three-Level Model (3LM) is a schematic conceptual framework that we hope will contribute to the process of the integration of naqli and aqli knowledge. This framework is designed to be easily understood, especially to knowledge workers who are not well versed in the philosophical aspects of 
Islamisation and Integration of Knowledge. We have used medical knowledge and practice as an example, but we also believe that this model is applicable in other fields of knowledge such as in engineering, finance, and the social sciences. Further work is required to test the practicality of this model among Muslim knowledge workers.

\section{REFERENCES}

1. Esposito JL. In: The Oxford Dictionary of Islam [online]. Available at www.oxfordislamic studies.com/article/opr/t125/32356. Accessed Mar 17, 2019.

2. Cambridge Advanced Learner's Dictionary and Thesaurus [online]. Available at https//:dictionary.cambridge.org/dictionary/ english/postivism. Accessed Mar 17, 2019.

3. Centre for Islamisation (CENTRIS), International Islamic University of Malaysia. IIUM Policies and Guidelines on Islamisation. Kuala Lumpur: 2013.

4. Universiti Sains Islam Malaysia. Integrasi Ilmu Naqli dan Aqli [online]. Available at https//:www.usim.edu.my/ms/integrasi-ilmunaqli-dan-aqli. Accessed Mar 17, 2019.

5. Al-Attas SMN. The concept of education in Islam. Kuala Lumpur: ISTAC, 1991.

6. Al-Faruqi IR. Islamisation of knowledge: General principles and workplan. Herndon: IIIT, 1982.

7. A-Alwani TJ. The Islamisation of Knowledge: Yesterday and today.Herndon: IIIT, 1995.

8. Othman MY. Universiti Kebangsaan Malaysia. In: Al-Quran \& Sains: Pemetaan rintis penyelidikan. Kuala Lumpur: IKIM, 2016.

9. Merriam-Webster Dictionary [online]. Available at https//:www.merriam-webster.com/ dictionary. Accessed Mar 17,2019.

10. Al-Attas SMN. The worldview of Islam: An outline. (Proceeding) Islam and the challenge of modernity: Historical and contemporary contexts. Kuala Lumpur: ISTAC, 1994.

11. Al-Quran. Al-Baqarah 2: 260. Sahih International: The Noble Qur'an [online]. Available at https//:quran.com. Accessed Mar 17,2019.

12. Abu Sulayman AH (ed). Islamisation of knowledge: General principles and workplan, 2nd ed. Herndon: IIIT, 1989.

13. Saifuddeen SM, Chang LW, Ibrahim AH, Mhd Khotib NA. Islamic ethical framework to tackle scientific and technological dilemmas. Journal of Dharma 2013; 4: 373-86.

14. Encyclopaedia Britannica [online]. Available at https//:www.britannica.com/topic/usul-al-fiqh. Accessed Mar 172019.

15. Usul al-Fiqh. In: The Oxford Dictionary of Islam [online]. Available at www.oxfordislamic studies.com/article/opr/t125/e2444. Accessed Mar 17, 2019.

16. Auda J. Maqasid al-Shariah on philosophy of Islamic law: A systems approach. London: IIIT, 2007.

17. Al-Qaradhawi Y. Ri'ayat al-Biah fi al-Shari'ah alIslamiyyah. Cairo: Dar al-Shuruq, 2001.

18. Ar-Rokki M. Nazariyyat-ut-Taq’id Al-Fiqhiy wa Atharuha fi Ikhtilaf Al-Fuqaha. Casablanca: AnNajah Al-Jadidah, 1994.

19. Enakmen Pentadbiran Perundangan Islam 1989, Fatwa tentang merokok. Jilid 48, No.25.

Selangor: Warta Kerajaan Negeri Selangor, 1995.

20. Enakmen Pentadbiran Hal Ehwal Agama Islam Negeri Pulau Pinang 1993, Fatwa Di Bawah Seksyen 36. Jilid 48, No.24. Pulau Pinang: Warta Kerajaan Negeri Pulau Pinang, 2004.

21. Ibn al-Qayyim al-Jawziyya. Ar-Ruh: The soul's journey after death. Delhi: Islamic Book Service, 2007.

22. Sahih Muslim \#2363 [online].(trans) Abu Amina Elias. Available at https://abuaminaelias.com/ dailyhadithonline/2011/05/19/the-prophetdistinguished-between-religion-and-science. Accessed on Apr 22, 2019.

23. Kasule OH. Islamic medicine: Concept and misunderstandings. Islamic Medical Education Resources [online]. Available at omarkasule01.tripod.com/id230.html. Accessed Mar 17, 2019.

24. Sahih Muslim \#1955 [online].(trans) Abu Amina Elias. Available at https:/ /abuaminaelias.com/ dailyhadithonline/2012/03/07/hadith-onexcellence-allah-prescribes-excellence-soslaughter-well-such-that-the-animal-feels-nopain. Accessed Apr 22, 2019. 